\title{
Aplikasi 3D Laser Scanner \\ Untuk Pemetaan Topografi dan Pendokumentasian \\ BCB Kawasan Situs Candi Gedong Songo
}

Oleh :

Brahmantara ST, Pramudianto D.H, Ajar Priyanto Balai Konservasi Peninggalan Borobudur

\section{Pendahuluan}

Candi Gedong Songo adalah nama sebuah kompleks bangunan candi peninggalan budaya Hindu yang terletak di Desa Candi, Kecamatan Ambarawa, Kabupaten Semarang, Jawa Tengah, Indonesia tepatnya di lereng Gunung Ungaran. Di kompleks candi ini terdapat 9 buah candi. Candi ini diketemukan oleh Raffles pada tahun 1804 dan merupakan peninggalan budaya Hindu dari zaman Wangsa Syailendra abad ke-9 (tahun 927 masehi).Candi ini memiliki persamaan dengan kompleks Candi Dieng di Wonosobo. Candi ini terletak pada ketinggian sekitar $1.200 \mathrm{~m}$ di atas permukaan laut sehingga suhu udara cukup dingin (berkisar antara $19-27^{\circ} \mathrm{C}$ ).

Pengelolaan Candi Gedong Songo sendiri berada dibawah instansi Pemda Propinsi Jawa Tengah dan Balai Pelestarian Peninggalan Purbakala (BP3) Jawa Tengah. Dengan letaknya yang berada pada dataran tinggi, kompleks candi yang terdiri dari 9 candi memiliki kontur dan topografi yang begitu rapat. Pendokumentasian keberadaan Candi Gedong Songo sangatlah perlu dilakukan mengingat letak posisi Candi Gedong Songo yang unik yang berada di atas perbukitan. Dalam usaha perekaman data topografi dan dokumentasi melalui fotoudara Bakosurtanal telah melakukan beberapa kali, namun data yang dihasilkan belum maksimal. Hal ini dapat di sebabkan karena letak kontur yang begitu terjal dan rapat. Dalam upaya meneruskan perekaman data tersebut maka Bakosurtanal bekerja sama dengan Balai Konservasi Peninggalan Borobudur melaksanakan penelitian mengenai pemetaan topograpi dan sistem pendokumentasian dengan basic $3 D$ Laser Scanner jotogrametri untuk kawasan situs Candi Gedong Songo.

\section{Tujuan Penelitian}

Penelitian ini bertujuan untuk mendapatkan data topografi kawasan situs dan dokumentasi Candi Gedong Songo dengan menggunakan alat HDS 3000 Laser Scanner.

\section{Manfaat Penelitian}

Manfaat yang dapat diperoleh dari penelitian ini adalah:

1. Mendapatkan data peta topografi (kontur, elevasi) kawasan Situs Candi Gedong Songo.

2. Mengetahui data dokumentasi (dimensi, letak) Situs Candi Gedong Songo.

3. Mengetahui kinerja dari Alat HDS 3000 Laser Scanner untuk Pemetaan Kawasan Situs Candi Gedong Songo.

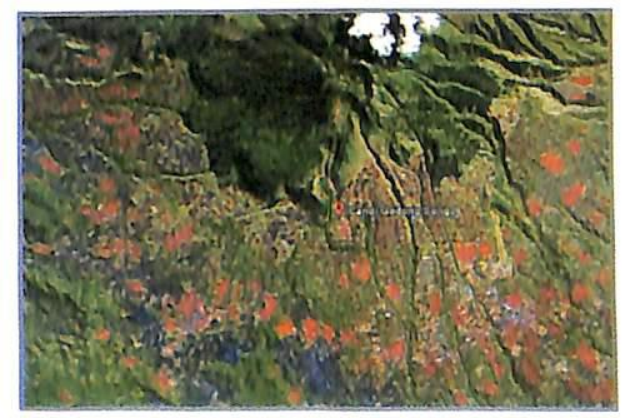

Gambar 1 Lokas Peneltuan dan pengarabulan Data

\section{Ruang Lingkup Penelitian}

Penelitian dan pengambilan data dibatasi pada area kawasan Situs Candi Gedong Songo yang meliputi Candi 1, Candi 2 dan Candi 3.

\section{Perekaman Data}

Pengambilan data scan dilapangan direncanakan selama 2,5 hari dengan alokasi waktu 0,5 hari pertama untuk pelaksanaan observasi awal yang berupa survey awal lokasi dan alur scan dan 2 hari selanjutnya untuk pelaksanaan scanning.

Data scan diambil untuk area Candi 1,2 dan 3 dengan luas total $\pm 1 \mathrm{~km}^{2}$. Dimulai dengan perekaman data pada candi 1 dan area sekelilingnya untuk mendapatkan data kontur tanah serta alur beda tinggi.

\section{Candi 1}

Posisi candi 1 terletak pada elevasi paling rendah dibandingkan kedua candi lainnya. Tahapan pengambilan data scanning:

a. scan image dengan settingan colour out door, level brightness pada tingkat middle;

b. target scan, untuk

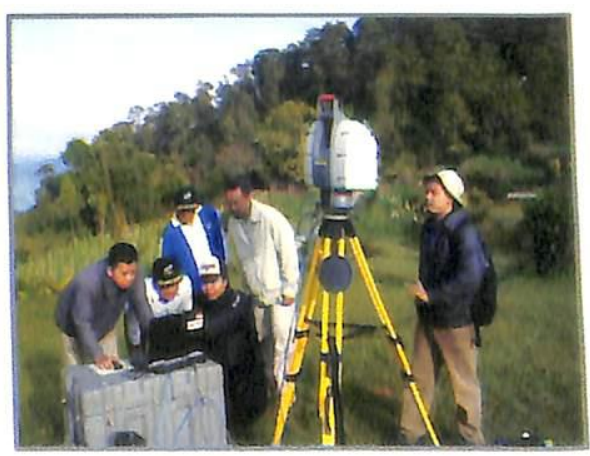


menggabungkan beberapa obyek scan dipasang beberapa target untuk candi satu dipasang 4 target. Scan pada target dilakukan dengan pengambilan spasi rapat untuk mendapatkan union obyek yang akurat;

c. scan obyek, pengambilan obyek scan untuk 1 obyek dilakukan minimal 2 titik b e r d i r u n t u k mendapatkan data clouds (titik-titik image) yang maksimal sehingga penggabungan obyek bisa utuh dan kompak. Spasing scan diambil $10 \mathrm{~cm}$ dalam kaitannya dengan waktu yang dibutuhkan untuk pengambilan scan. Semakin besar spasi yang diambil maka waktu yang dibutuhkan akan semakin singkat.

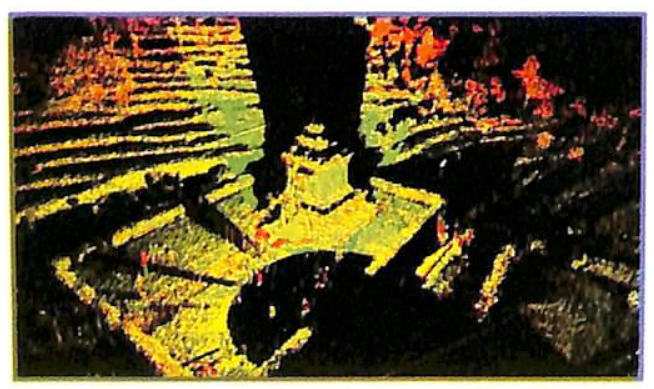

Gambar 2. Point clouds obyck scan titik Timur

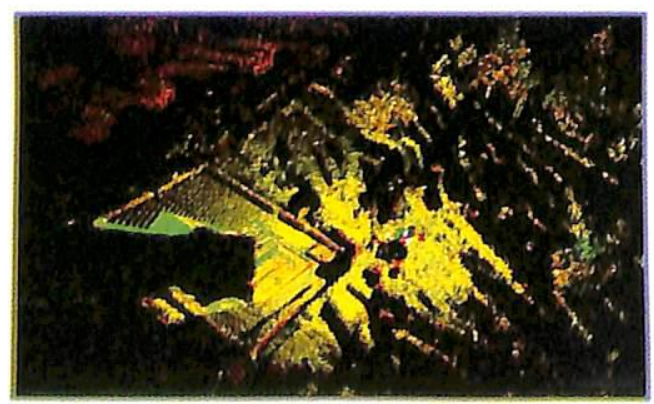

Gambar 3. Point clouds obyek scan titik Barat

c. Union obyek, merupakan tahapan penggabungan hasil scan dari beberapa titik point clouds.

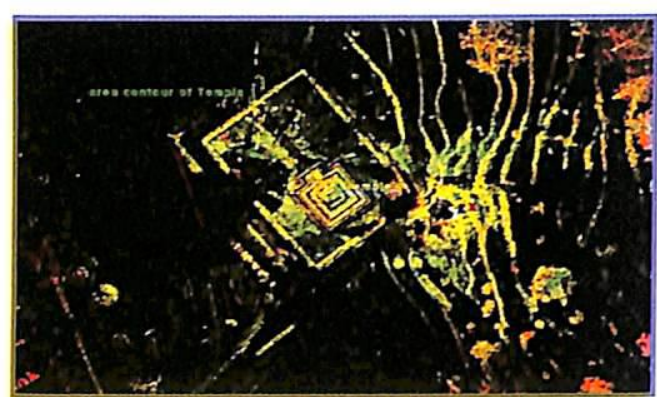

Gambar 4. Union obyek scan titik 1 dan 2

\section{Candi 2}

Candi 2 terletak di posisi setelah candi 1 , sehingga elevasi pada candi 2 lebih tinggi dibandingkan candi 1 . Tahapan pengambilan data scan seperti halnya pada candi 1 namun ditambah dengan pengambilan obyek alur jalan menuju candi 2

3. Candi 3

Candi 3 terletak pada elevasi

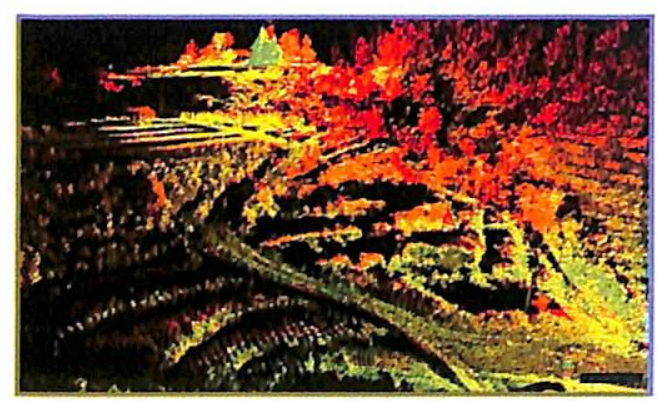

Gambar 5. Alur topographic jalan menuju candi 2

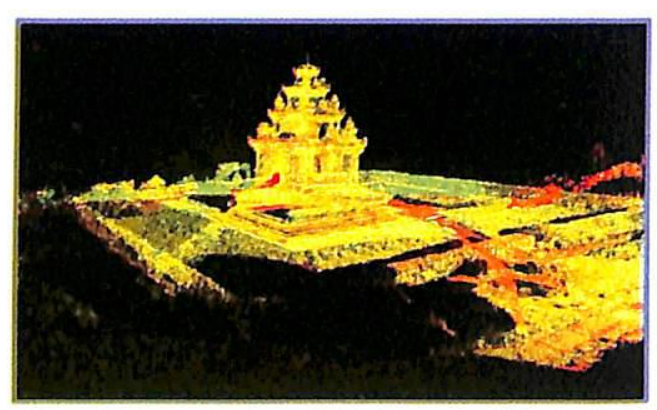

Gambar 6. Detail point clouds candi 2

paling atas dibandingkan candi 1 dan 2 , jarak antara candi 2 dan 3 lebih dekat dibandingkan jarak candi 1 ke 2, jadi untuk pengambilan data dan penggabungan bisa dilakukan secara bersamaan satu alur scan.

\section{Penggabungan (union) Data}

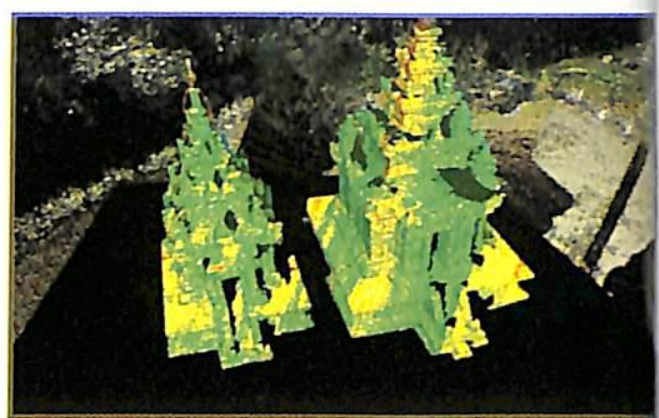

Gambar 7. Detal point clouds candi 3

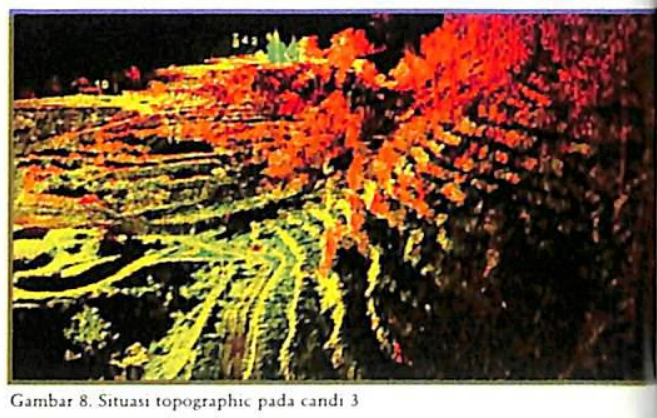

Untuk penggabungan data digunakan dua metode:

1. Metode penggabungan dengan target.

Metode ini sangat efektif dan lebih akurat untuk output hasil yang lebih dibobotkan pada aspek geodetic. Dimensi, elevasi bentuk dan ukuran yang didapatkan sesuai dengan data yang ada dilapangan (error measurement sangat kecil)

2. Metode penggabungan clouds to clouds.

Untuk mendapatkan data geodetic obyek yang akurat metode ini kurang efektif digunakan karena error measurement yang dihasilkan lebih besar. Metode ini cenderung efektif digunakan untuk mendapatkan obyek yang berupa viewer dan landscape area.

Pada pengambilan data obyek scan candi 1,2 dan 3 kompleks percadian Dieng digunakan metode penggabungan dengan target karena hasil yang diinginkan adalah data kontur, data dimensi dan ukuran bangunan candi yang benar-benar sesuai dengan data dilapangan.

Metode penggabungan ini 
dilakukan pada obyek candi 2 dan 3 karena pengambilan scan pada kedua obyek ini bisa menyatu dengan beberapa alur scan. Untuk penggabungan candi 1 ke 2 dan 3 tidak bisa dilakukan karena alur
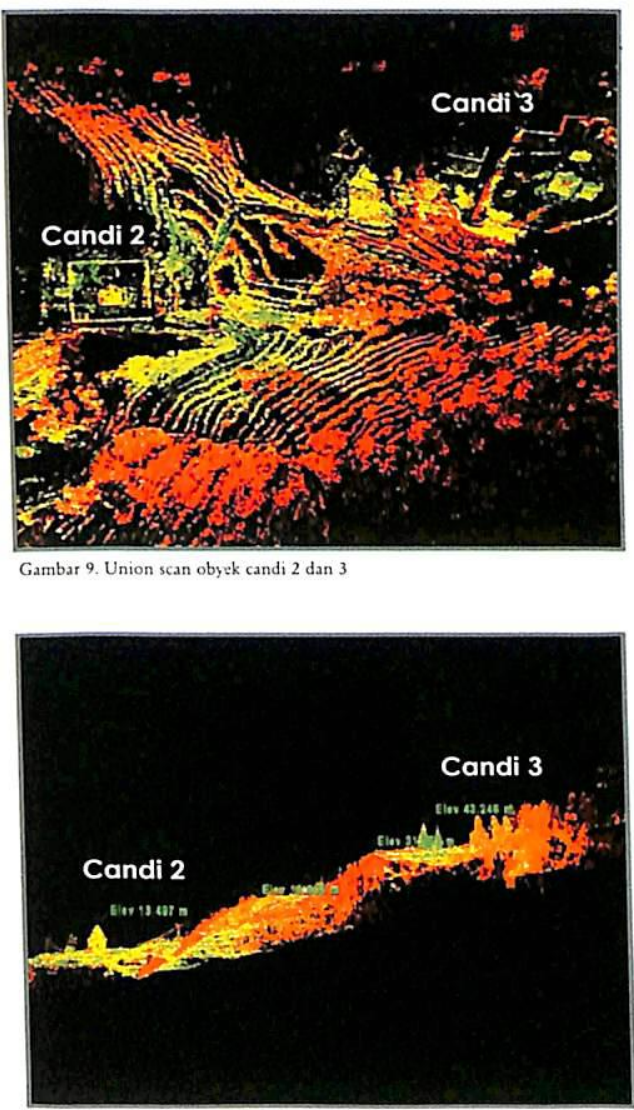

Gambar 10. Potongan melintang candi 2 dan 3

pengambilan scan tidak menyatu sampai candi 1 .

\section{Analisa Data Topograpic}

Scan obyek pada area candi dan lingkungannya digunakan untuk mengaplikasikan analisa data topographic yang berupa kontur tanah. Analisa data topographic ini kita lakukan untuk obyek pada candi 1 karena data scan pada obyek ini kerapatan point clouds yang dihasilkan lebih halus, bersih dan rapat.

Pembuatan kontur dilakukan dengan langkah:

1. Hasil scan obyek yang berupa Point clouds kita bersihkan

terlebih dahulu, karena dengan setingan kerapatan yang kita pakai kemungkinan obyek -obyek yang tidak diharapkan seperti debu, rumput-rumput akan tertangkap laser sehingga hal ini akan sangat mengganggu analisa dan pembuatan kontur lereng.

2. Setelah obyek scan point clouds kita bersihkan selanjutnya kita

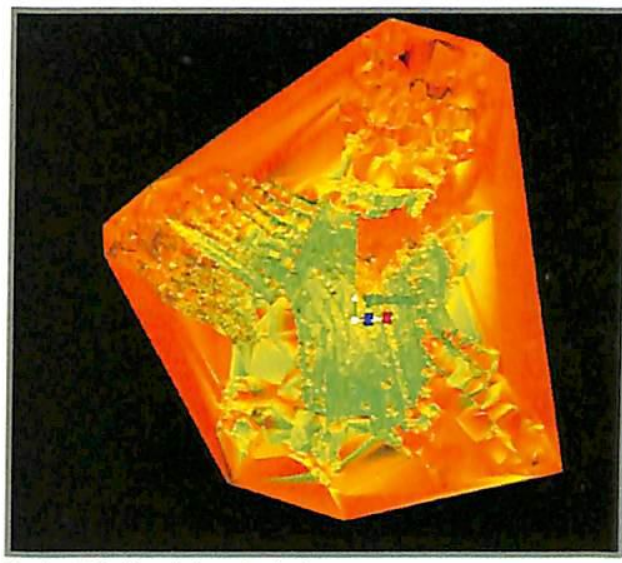

Gambar 12. Hasil mesh data point clouds

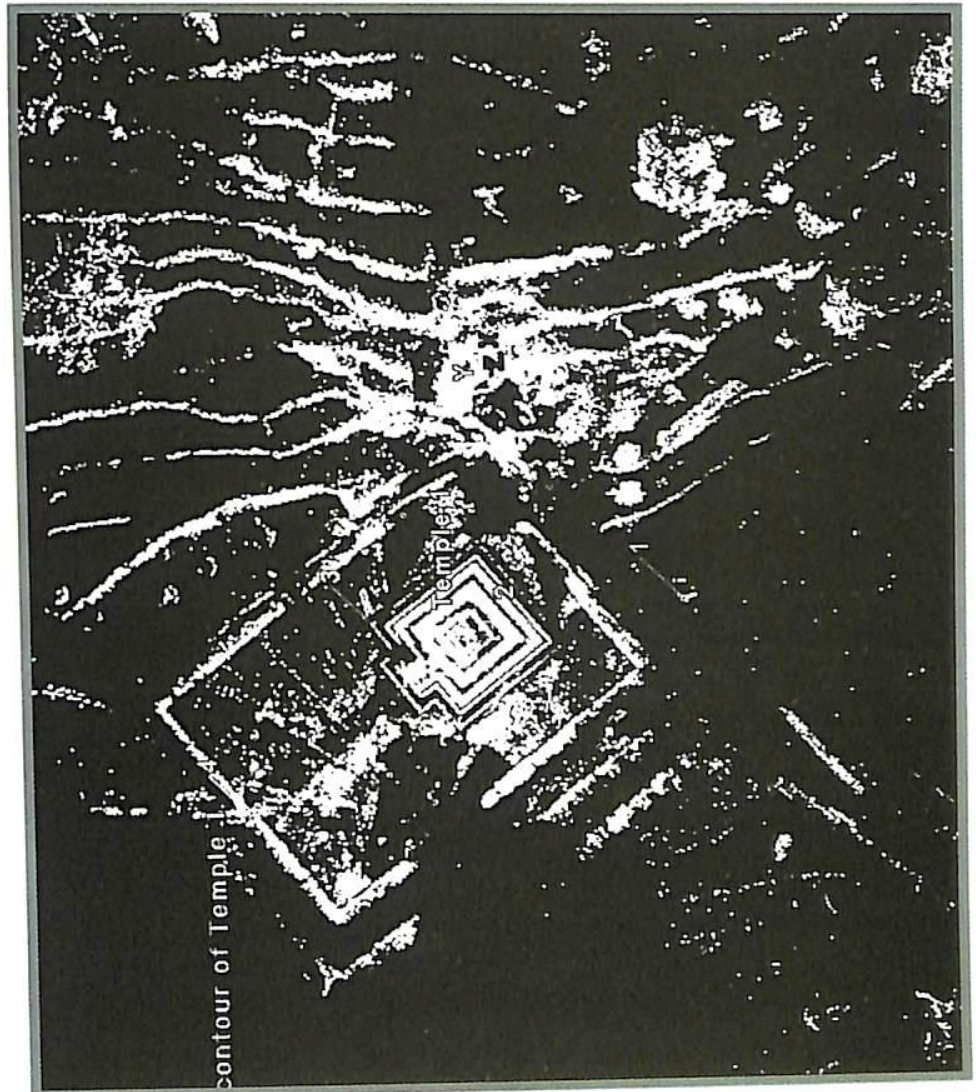

mengganggu analisa kontur 1 e r e n g. Setelah data mesh kita dapat maka $1 \mathrm{a} \mathrm{k} \mathrm{u} \mathrm{k} \mathrm{a} \mathrm{n}$ execusi perint a h $\mathrm{k} O \mathrm{n} \mathrm{t} u \mathrm{r}$ $\mathrm{d}$ e $\mathrm{n} \mathrm{g}$ a $\mathrm{n}$ i n $\mathrm{ter}$ a 1 kontur kita ambil $5 \mathrm{~m}$. I $\mathrm{nte} r \mathrm{val}$ kontur yang diambil tidak $\mathrm{h}$ a r u s 5 meyesuaikan $\mathrm{d}$ e $\mathrm{n} \mathrm{g}$ a $\mathrm{n}$ bentuk dan kondisi obyek scan yang kita teliti. Interval 5 ini kita

lakukan perintah mesh, mesh digunakan untuk menyatukan point clouds yang berupa data titik titik obyek menjadi sebuah obyek yang rapat dan masiv, dengan kata lain tidak ada rongga-rongga pada point clouds jadi obyek benar-benar menjadi sebuah obyek masiv dan utuh.

3. Dari hasil mesh obyek akan kita ketahui apakah obyek scan sudah benar-benar bersih dari debu dan data-data lain yang ambil karena obyek yang kita teliti berada didaerah pegunungan sehingga beda tinggi yang ada akan sangat berimpitan.

VIII. Kesimpulan

Ada beberapa kesimpulan yang bisa diambil dari penelitian ini antara lain:

1. Pemetaan dan perekaman data khususnva obvek BCB sangat 
diperlukan untuk mendapatkan data yang benar-benar akurat, sehingga data tersebut dapat
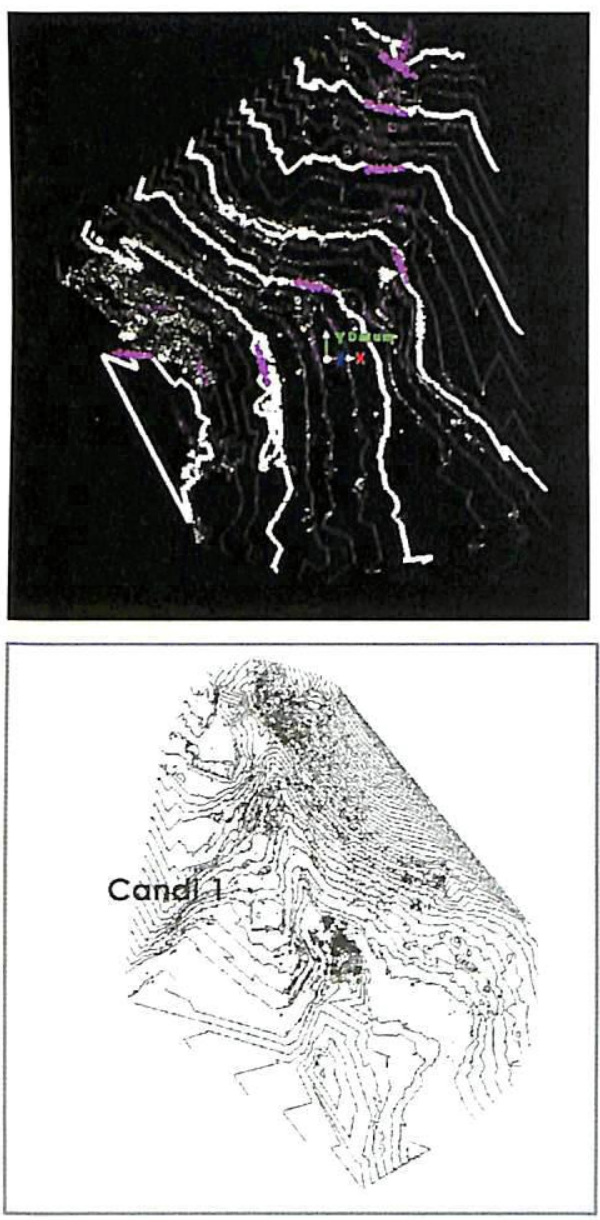

Gambar 13. Hasil kontur area candi I dengan interval $5 \mathrm{~m}$ digunakan sebagai acuan untuk rencana pengembangan, pemugaran dan konservasi;

2. Aplikasi 3D laser scanner sangat efektif untuk perekaman data sampai pada data 3 dimensi obyek $\mathrm{BCB}$ dengan hasil yang sangat akurat sesuasi dengan keadaan di lapangan;

3. Analisa Topograpic area pada kompleks Candi Gedong Songo dengan menggunakan HDS 3000 laser scanner menghasilkan data yang sangat akurat dan cepat;

4. Perlu dilakukan penelitian lanjutan mengenai kemungkinan pengembangan-pengembangan yang lebih jauh mengenai sistem perekaman data dan pemetaan obyek BCB .

\section{Daftar Pustaka}

Andrea Lingua, Paolo Piumatti, Fulvio Rinaudo Digital

photogrammetry: A standart approach to cultural heritage survey.

In: The international Archives of

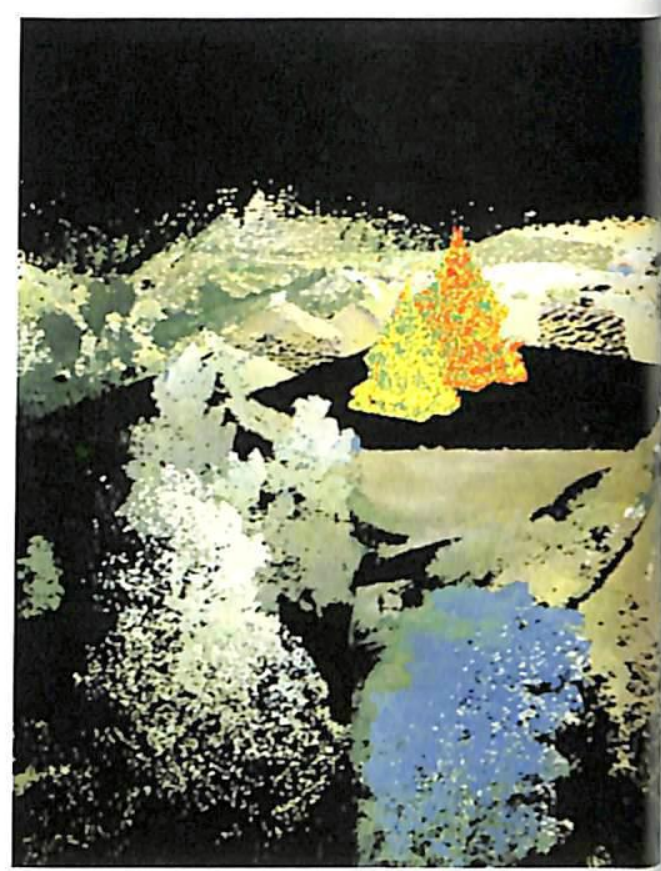

Candi III, Kompleks Candi Gedong Songo

3D Image Point Cloud

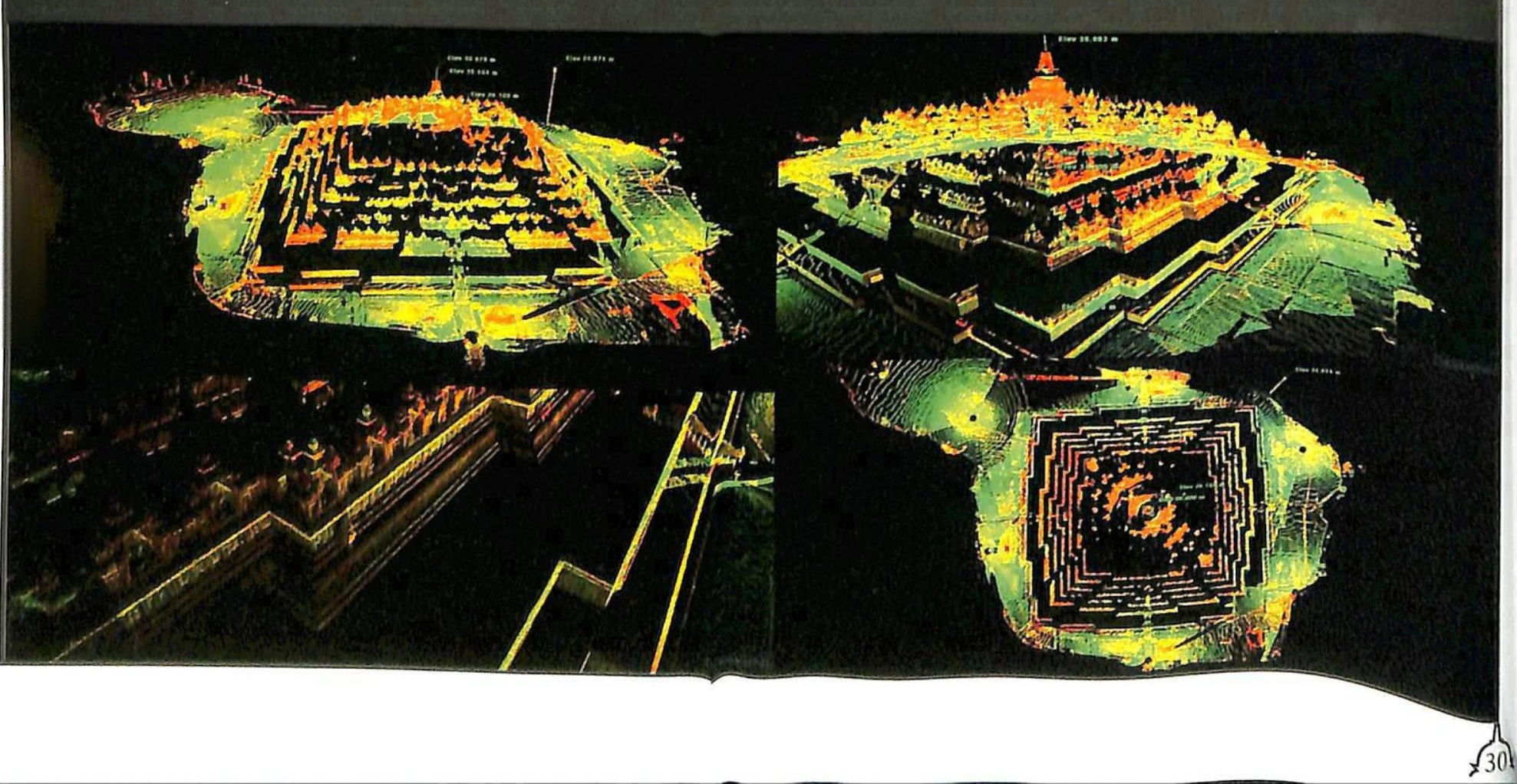

